\title{
ヒト睪丸胎児性癌細胞の表面マーカー
}

$\begin{array}{lllll}\text { 新潟大学医学部第 } 1 \text { 病理学教室 } & \text { 本 } 4 \text { 悌 } & \text { 一 } \\ & \text { 新潟大学医学部泌尿器科学教室 } & \text { 本 } & \text { 尊 彦 } \\ & \text { 藤 } & \text { 昭 } & \text { 太 } & \text { 郎 }\end{array}$

\section{SURFACE MARKERS ON HUMAN TESTICULAR EMBRYONAL CARCINOMA CELLS}

\author{
Teiichi Motoyama \\ 1st Department of Pathology, Niigata University School of Medicine, Niigata, Japan \\ Takahiko Yamamoto and Shohtaroh Satoh \\ Department of Urology, Niigata University School of Medicine, Niigata, Japan
}

The present study deals with F9-like antigens, major histocompatibility antigens (HLA-A, B, C and $\beta_{2}$-microglobulin) and lectin-receptors on the cell surfaces of human embryonal carcinoma (EC) cells. Four cell lines used in the present study were derived from testicular germ cell tumors.

Although the presence of F9-like antigens was suggested in these human EC cells, they also had major histocompatibility antigens. In this point human EC cells differ from mouse EC cells. However, the levels of $\beta_{2}$-microglobulin in the media suggested that HLA was in very small amounts. There are receptors to PNA, UEA-I and DBA on the cell surfaces of human EC cells also. The DBA receptors on human EC cells are far less than on mouse EC cells.

The surface markers of human EC cells do not completely agree with those of mouse EC cells. The expression of surface makers have no connection with the ability of differentiation in human EC cell lines.

要旨：ヒト辤丸肧細胞腫瘍由来の胎児性癌培養細胞 4 株について, その細胞表面上に F9様抗原が存在す るか否か，あるいは主要組織適合性抗原（HLA-A, B, C および $\beta_{2}$-microglobulin）が発現されているか 否かについて調べ，またレクチンレセプターの有無について検索した。

ヒト胎児性癌細胞（EC 細胞）では 4 株ともF9様抗原の存在が示唆されたにもかかわらず, 主要組織 適合性抗原の発現も認められ，この点マウス奇形癌腫に拈ける EC 細胞とは異った。 しかし， $\beta_{2}$-microglobulinの量から考光, HLA も極めて微量であることが推測された。

細胞表面には PNA, UEA-I, DBA などのレクチンレセプターの存在も認められたが，ヒト EC 細胞に 扣いては DBA レセプターはマウス EC 細胞活ど多くはなかった。

このようにヒト EC 細胞とマウス EC 細胞との間に完全な一致は見なかった. また, 表面マーカーの存 在の有無执よびその程度は, 各細胞株の持つ分化能力とも相関しなかった。

\section{緒 言}

ヒト胚細胞腫瘍，とりわけ胎児性癌は多様な組織像 をとること,しばしば奇形腫を合併することなどから， マウスに打ける奇形癌腫と同様の性格を持った腫瘍で はないかと目されることが多い，しかし，マウス奇形 癌腫細胞が正常の体細胞にまで分化し得ることが実証 されている11のに対し，ヒト胎児性癌の分化能につい てはいまだ状況証拠による憶測の域を出ていない。ま た，ヒト胎児性癌の未分化性あるいは胎児性といった
性格に関しても確かな位置づけはなされていない。

Stevens と Hummel ${ }^{2}$ により睪丸に奇形腫が自然発 生する129系統のマウスが発見されて以来, マウスの実 験系を用いた実験腫瘍学および実験発生学は今日まで 数々の驚異的な成果を得てきた。

現在多くの研究者によって認められているマウス奇 形癌腫の特徵をまとめると次のよらになる.

1. マウスでは, 奇形癌腫 (teratocarcinoma) の幹 細胞ともいうべき胎児性癌細胞 (embryonal car- 
cinoma cell : EC 細胞）は, 初期胚の細胞と同様の多 分化能を保持している.

2. EC 細胞の表面には主要組織適合性抗原は存在 しない.

3. EC 細胞は，PNA，Lotus A, DBA に対するレセ プターを有しているが，そこから分化した細胞ではこ れらのレクチンレセプターを失っている.

4. EC 細胞の表面マーカーとなるレクチンレセプ ターあるいは表面抗原は，高分子量糖ペプチドに荷わ れている。

以上の性格のらち特に 2 から 4 についてヒト睪丸由 来の胎児性癌培養細胞 4 株を用い，ヒトの場合につい て検討した。 その結果, ヒト $\mathrm{EC}$ 細胞とマウス $\mathrm{EC}$ 細胞 との類似点拉よび相違点の一端を明らかにしえたので 報告する。

\section{1. 培養細胞株}

七ト睪丸肧細胞腫瘍由来の胎児性癌培養細胞株と乙 て ITO, NEC8, NEC14, NEC15の 4 株3) 5)を用いた。 各々の主な性質を Table 1に示した。

対照として, マウス奇形癌腫 OTT 6050由来の F96), ヒトBurkittリンパ腫由来で $\beta_{2}$-microglobulinを欠 くDaudi?)，その他にヒトBurkittリンパ腫由来の $\mathrm{BT}-1^{8)}$ ， ヒト䄉毛癌由来の $\mathrm{GCH} 1^{9)}$ ， GCC-SV ${ }^{10)}$, Lu$75^{10)}, \mathrm{SCH}^{11)}$, ヒト胃癌由来の $\mathrm{MKN} 28^{12)}, \mathrm{MKN} 45^{12)}$, それに健常ヒトリンパ球 MTCをそれぞれ必要に応じ て用いた。

\section{2. マウス抗 F9血清}

Artzt ら ${ }^{6)}$ の方法に従い,コバルト60で前処置した細 胞を129/Sv 雄マウスに免疫することによって得た。こ れを上述の MKN45細胞で吸収操作した後蛍光抗体法 に用いた。

3. 抗 HLA 拉よび抗 $\beta_{2}$-microglobulin 抗体

抗 HLA：ABC モノクローナル抗体 $(W 6 / 32)^{13)}$ は Sera-Lab 社(England)より, 抗ヒト $\beta_{2}$-microglobulin
モノクローナル抗体 (SRL-1) は Paesel 社 (West Germany）ょり購入した。

4. 蛍光抗体法

間接蛍光抗体法を用いた。 Lab-tek chamber slide

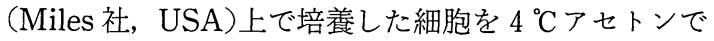
15 分間固定した後，1次抗体を室温で30分間作用させ た. 2 次抗体は Dako 社 (Denmark) の FITC 標識抗 マウス免疫グロブリンを用い，室温で60分間作用させ た。

5. $\beta_{2}$-microglobulin の定量

対数增殖期中期に継代を繰返すことにより未熟細胞 を集めた後, $2 \times 10^{5}$ 個の細胞を $60 \times 15 \mathrm{~mm}$ の Lux プラ スチックディッシュ（Miles 社, USA) に $3 \mathrm{ml}$ の培養 液とともに植込み，初回は24時間後次いで48時間毎に 培養液を交換した。培養液上清中の $\beta_{2}$-microglobulin は固相法 radioimmunoassay (Pharmacia 社, Sweden)により測定した。単位細胞あたりの分泌量は 細胞増殖曲線と $\beta_{2}$-microglobulin 定量曲線より算出 した.

6. レクチン

Arachis hypogaea (ピーナッツ), Dolichos biflorus (ヒマラヤふじ豆)および Ulex europeus（ハリェニシ ダ)由来のレクチンを用いた. Table 2に常用される略 名と特異的糖結合性などの主な性質を示した。UEA-I は Lotus A と同様 $\alpha$-L-Fucose と特異的に結合するの で，ここでは代わりに用いた，FITC 標識レクチンは $\mathrm{E} ・ \mathrm{Y}$ 社（USA）より購入した。

Lab-tek chamber slide上で培養した細胞を未固定 のまま $100 \mu \mathrm{g} / \mathrm{ml}$ の FITC 標識レクチンで室温で30分 間作用させた。各々の特異性は $0.2 \mathrm{M}$ の特異糖溶液に よる阻害試験により確認した。

\section{結果}

1. 間接蛍光抗体法による試験

間接蛍光抗体法による試験結果を Table 3に示し た. マウス抗 F9血清により F9細胞はほぼ100\%陽性蛍

Table 1. Human testicular embryonal carcinoma cell lines used in present study

\begin{tabular}{c|c|c|c}
\hline $\begin{array}{l}\text { Cell line } \\
\text { designation }\end{array}$ & Originator & $\begin{array}{l}\text { Histological type } \\
\text { of origin }\end{array}$ & $\begin{array}{c}\text { Ultrastructural cell } \\
\text { type of cultured cell }\end{array}$ \\
\hline ITO & Sekiguchi, M. & Y/S/Ti & Y \& A \\
NEC 8 & Yamamoto, T. & A & A \\
NEC 14 & Yamamoto, T. & A/Y & A \& Y \\
NEC 15 & Yamamoto, T. & A/C & A \\
\hline
\end{tabular}

A : Embryonal carcinoma of adult type, Y : Yolk sac tumor (embryonal carcinoma of infantile type), S : Seminoma, Ti: Immature teratoma, C: Choriocarcinoma 
Table 2. Biochemical properties of lectins used in present study

\begin{tabular}{|c|c|c|c|c|c|}
\hline Origin & Abbreviation & M. W. & $\begin{array}{l}\text { Sugar } \\
\text { specificity }\end{array}$ & $\begin{array}{l}\text { Blood } \\
\text { type }\end{array}$ & $\begin{array}{l}\text { Mitogenic } \\
\text { activity }\end{array}$ \\
\hline $\begin{array}{l}\text { Arachis hypogaea } \\
\text { (Peanut) }\end{array}$ & PNA & 110,000 & $\begin{array}{l}\text { D-Gal } \beta(1,3) \text { - } \\
\text { GalNAc }\end{array}$ & Anti $T$ & + \\
\hline $\begin{array}{l}\text { Dolichos biflorus } \\
\text { (Horse gram) }\end{array}$ & $\mathrm{DBA}$ & 140,000 & $\alpha$-D-GalNAc & A & - \\
\hline $\begin{array}{l}\text { Ulex europeus } \\
\text { (Gorse) }\end{array}$ & UEA-I & 170,000 & $\alpha$-L-Fucose & $\mathrm{O}(\mathrm{H})$ & + \\
\hline Lotus tetragonolobus & Lotus A & 120,000 & $\alpha$-L-Fucose & $\mathrm{O}(\mathrm{H})$ & + \\
\hline
\end{tabular}

Gal: Galactose; GalNAc: N-acetyl-galactosamine; GlcNAc: N-acetyl-glucosamine

Table 3. Indirect immunofluorescence assays for surface antigens of cultured cells

\begin{tabular}{l|c|c|c|c}
\hline Cell line & Anti-F9 & $\begin{array}{c}\text { Anti-F9 } \\
\text { absorbed on F9 }\end{array}$ & $\begin{array}{c}\text { W6/32 } \\
\text { (anti-HLA) }\end{array}$ & $\begin{array}{c}\text { SRL } \\
\text { (anti- } \beta_{2} \text {-microglobulin) }\end{array}$ \\
\hline ITO & $+{ }^{\text {a) }}$ & - & + & + \\
NEC 8 & \pm & - & + & + \\
NEC14 & \pm & - & + & + \\
NEC15 & \pm & - & - & + \\
Daudi & - & n.d. & - & - \\
F9 & + & - & n.d. & + \\
MTC & - & n. & + \\
\hline
\end{tabular}

a) Intensity of positive findings from weak to strong; not seen (-)

b) n.d. : not done

光を示し, ITO 株では10\%以下の細胞であるが明らか な陽性所見が認められた（Fig. 1). NEC8， NEC14, NEC15の 3 株でも $5 \%$ 以下の細胞に弱いながらも陽 性所見が認められた。

抗 HLA (W6/32) に対しては, ヒト胎児性癌は 4 株 とも数\%の少数の細胞ではあるが明らかな陽性所見を 呈し (Fig. 2), 抗ヒト $\beta_{2}$-microglobulin (SRL-1) に 対しても同様の所見が得られた。

2. 培養上清中の $\beta_{2}$-microglobulin 量

培養上清中に放出される $\beta_{2}$-microglobulinの量を

Fig. 1 Immunofluorescence study on ITO cells with anti-F9 antibody. $\times 200$.

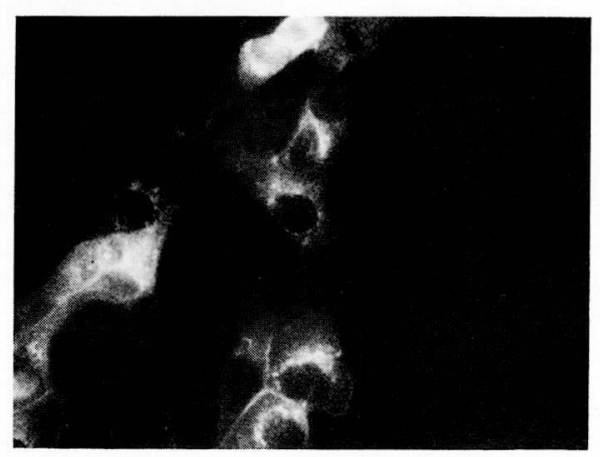

調べると, 胎児性癌ではいずれも対数増殖期に多いと いら特徴的なパターンを示した. ITO 株と NEC8株の 例をそれぞれFig. 3と Fig. 4に示す。これに対し，通 常の体細胞由来の癌ではすべて培養日数とともに漸増 するといら傾向を示した．胃癌由来の MKN28株の例 をFig. 5に示す，さらに，胎児性癌ではその分泌量は いずれも少なく，単位細胞あたりの量は最大のときに 批いてさ兄, 体細胞由来の癌, 例觉ば胃癌の最小值に も及ばなかった。絨毛癌に打いては, 検索した妊娠性 䄉毛癌 3 株中 2 株はその最大值は体細胞由来の癌とほ

Fig. 2 Immunofluorescence study on ITO cells with anti-HLA antibody. $\times 200$.

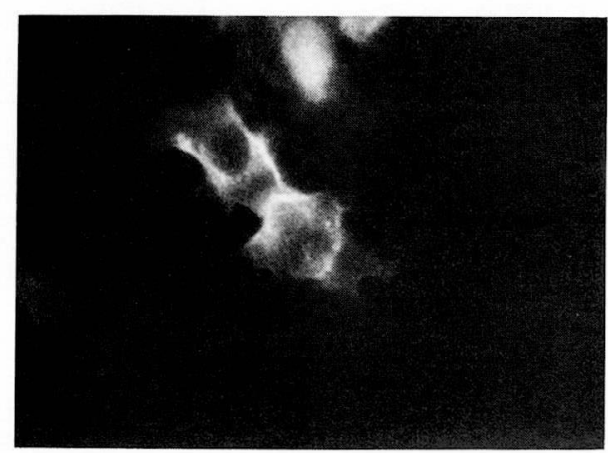


Fig. 3 Growth curve and $\beta_{2}$-microglobulin level of ITO cell line

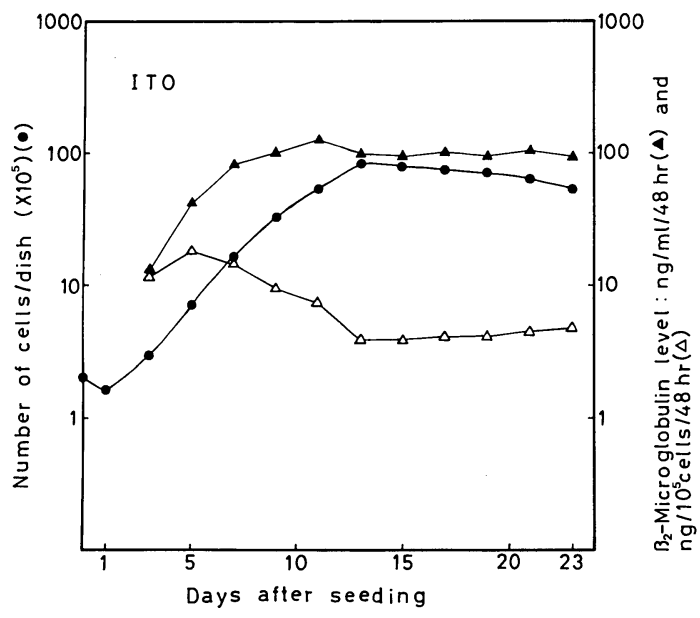

Fig. 4 Growth curve and $\beta_{2}$-microglobulin level of NEC8 cell line

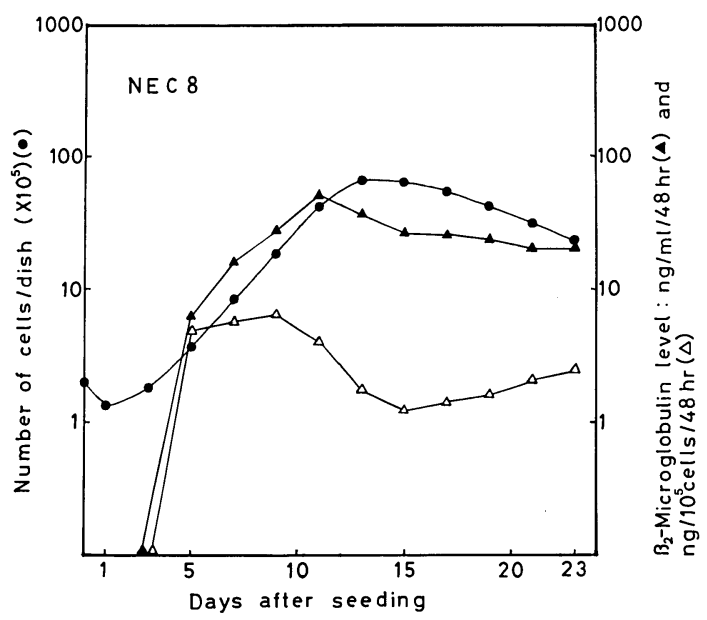

ぼ同じ水準であるが，最小值はかなり低值であった。 これに対し, 胎児性癌株に括いては最大值は最も低い 絨毛癌よりもさらに低く, 最小值もきわめて低值で あった (Table 4).

3.レクチンレセプター

ヒト胎児性癌に拈いては, DBAレセプターは NEC 14株を除きごく少数の細胞にしか認められなかった が, PNA レセプター, UEA-Iレセプターはかなりの数 の細胞に認められた（Table 5)，Fig. 6 にITO株の PNA レセプターを示す.

$$
\text { 考 察 }
$$

Artzt ら
Fig. 5 Growth curve and $\beta_{2}$-microglobulin level of MKN 28 cell line

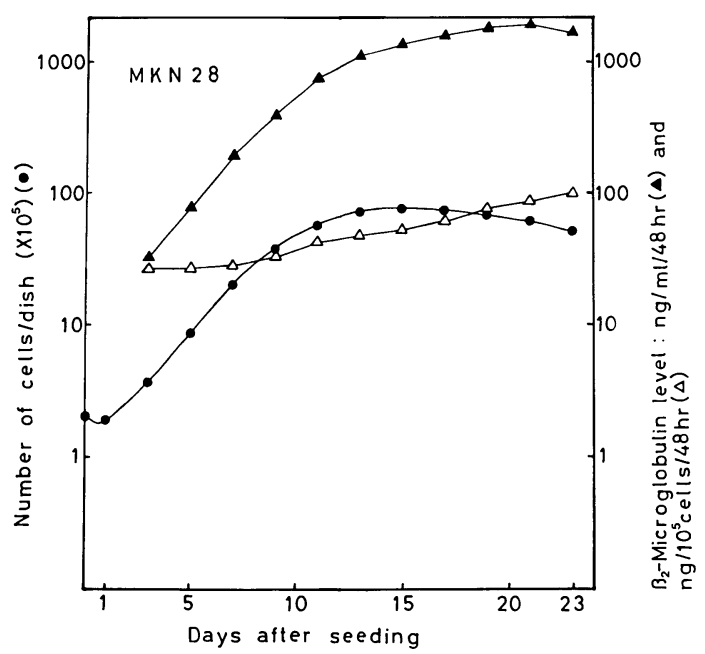

Table 4. Beta-2-microglobulin secretion from cultured human tumor cells

\begin{tabular}{l|r|c}
\hline \multicolumn{1}{c|}{ Cell line (origin) } & \multicolumn{2}{c}{$\begin{array}{c}\text { Maximum } \\
\text { (ng/105 }\end{array}$} \\
& $\begin{array}{c}\text { Minimum } \\
\text { cells/48hr) }\end{array}$ \\
\hline ITO (embryonal carcinoma) & 6.5 & 3.6 \\
NEC 8 (embryonal carcinoma) & 8.4 & 0 \\
NEC14 (embryonal carcinoma) & 11.4 & 0 \\
NEC15 (embryonal carcinoma) & 0 & 0 \\
Daudi (Burkitt lymphoma) & 51.3 & 12.0 \\
BT-1 (Burkitt lymphoma) & 20.9 & 0 \\
GCH 1 (choriocarcinoma, gestational) & 79.6 & 9.8 \\
GCC-SV (choriocarcinoma, gestational) & 61.5 & 8.3 \\
Lu-75 (choriocarcinoma, gestational) & 78.0 & 15.1 \\
SCH (choriocarcinoma, stomach) & 103.6 & 25.9 \\
MKN28 (gastric cancer, tub.) & 72.8 & 29.5 \\
MKN45 (gastric cancer, por.)
\end{tabular}

Table 5. Receptors for fluorochrome-coupled lectins in human testicular embryonal carcinoma cells and F9 cells in vitro

\begin{tabular}{l|c|c|c|c}
\hline Cell line & $\begin{array}{c}\text { Blood type } \\
\text { of patient }\end{array}$ & PNA & DBA & UEA-1 \\
\hline ITO & A & $+^{\text {a) }}$ & \pm & + \\
NEC 8 & A & + & \pm & + \\
NEC14 & A & + & + & + \\
NEC15 & A & + & \pm & + \\
F9 & - & + & \# & + \\
\hline
\end{tabular}

a) Intensity of positive findings from weak to strong ; not seen (-) 
Fig. 6 Binding of PNA to ITO cells. $\times 400$.

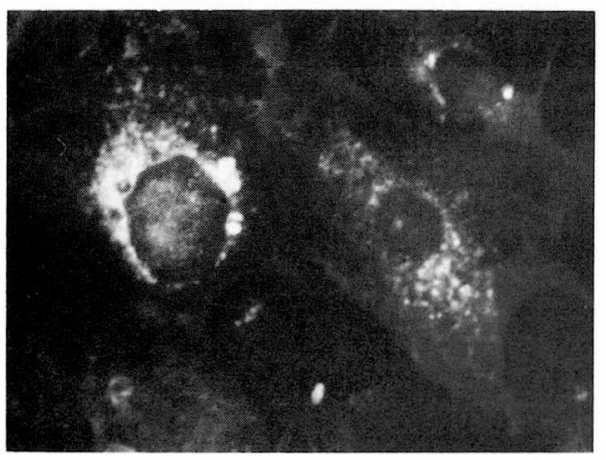

一種 F9細胞を放射線処理した後, れを抗原としてそ の同系宿主である129/Sv雄マウスを過免疫すること により $\mathrm{F}$ 細胞と強い抗原抗体反応を起す抗血清を得 た.この抗血清で検出できる抗原が通常 F9抗原とよば れている，F9抗原はマウス由来のすべての EC 細胞株 の細胞表面に存在し，また 2 割球期胚より 8 日目初期 肧の内部細胞塊にまで存在する。成体では精子を除き ほとんどすべての細胞に存在しない，EC 細胞も分化 をとげると抗原性は消失する ${ }^{14)}$.一方, マウスの主要組 織適合性抗原である H-2抗原は, EC 細胞や初期胚に は存在しないが，分化した細胞では認められるように なり，成体ではほとんどすべての臓器の細胞に存在す る ${ }^{14)}$. F90ほかに EC 細胞执よび初期胚に見出される 抗原としては, やはり F9細胞を抗原として作製したモ ノクローナル抗体によって桑実胚から着床前卵の内部 細胞塊に認められる Stage specific embryonic antigen-1 (SSEA-1) や15), さらには PCC4 ${ }^{16)}, 2 \mathrm{C} 5^{17) な ~}$ ぞかなりの数のものが現在まで知られている。これら は分化抗原としての意味を持ち，またヒト初期胚にお
ける分化抗原が明らかにされていないため，ヒト胚細 胞腫瘍の検索にもこれらの応用が試みられてきた。 ヒ 卜胚細胞腫瘍血清中に F9様抗体が存在するといら報 告もマウスとヒトの EC 細胞にかなりの類似性がある ことを示唆する ${ }^{18)}$.

ヒト胚細胞腫瘍由来の培養細胞株を用い, F9様抗原 の有無, HLA の発現の有無などについて調べた主な 報告をわれわれなりになとめると Table 6のようにな る. Hogan ら ${ }^{19)}$ が Susa 細胞に F9様抗原を見出して以 来現在まで幾つかの報告がなされている。、ウスの $\mathrm{EC}$ 細胞では F9抗原が存在し, 主要組織適合性抗原 $\mathrm{H}$ 2は存在しないが，ヒト EC 細胞でも Tera-II 株などは これと同じ傾向を示す20). ところが, $833 \mathrm{~K}-\mathrm{E}$ 株は F9様 抗原を持ちながら, HLA が発現されている細胞も存 在する ${ }^{21)}$. PA-1株ではF9抗体と反応する細胞はない が， EC 細胞と精子拉よび着床囊胞胚の内部細胞に見 出される PCC4は存在し, HLA の発現もある ${ }^{22)}$. われ われの検索した 4 株はいずれも HLA の発現があり, から F9様抗原の存在も示唆された。これは $833 \mathrm{~K}-\mathrm{E}$ 株, Susa 株, Tera-I株などと類似の性質を示している. ヒ トの EC 細胞に HLA が存在することはAndrews $ら^{23)}$, Avner ら ${ }^{24)}$ にっても認められている。この点 はマウス $\mathrm{EC}$ 細胞と相違する性格である。しかしなが ら, HLA の subunit である $\beta_{2}$-microglobulin が培養 液中に遊離される量で HLA の発現程度を推測できる とするならば，胎児性癌における培養液中の $\beta_{2}$-microglobulin はきわめて少量であることから，ヒト EC 細胞では HLA は発現されてはいるがきわめて微量で あると推測される。ヒトの EC 細胞に初期肧の分化抗 原も主要組織適合性抗原も認められるということは, 未分化な細胞と比較的分化した細胞とが混在している

Table 6. Expression of surface antigens on cultured human germ cells tumors

\begin{tabular}{|c|c|c|c|c|c|c|}
\hline Cell line & $\begin{array}{l}\text { Origin, age, sex } \\
\text { (Histological type) }^{a}\end{array}$ & F9 & SSEA-1 & PCC4 & HLA & $\beta_{2}$-Microglobulin \\
\hline Susa & $\begin{array}{l}\text { Testis, } 30, \mathrm{M} . \\
(\mathrm{E} / \mathrm{T})\end{array}$ & + & n.d. ${ }^{\text {b) }}$ & n.d. & \pm & \pm \\
\hline Tera-I & $\begin{array}{l}\text { Testis, 47, M. } \\
\text { (E) }\end{array}$ & + & n.d. & n.d. & \pm & \pm \\
\hline Tera-II & $\begin{array}{l}\text { Testis, } 22, \mathrm{M} . \\
\text { (E) }\end{array}$ & H & n.d. & n.d. & - & - \\
\hline 833K-E & $\begin{array}{l}\text { Testis, 19, M. } \\
(\mathrm{E} / \mathrm{C} / \mathrm{T} / \mathrm{S})\end{array}$ & n.d. & H & n.d. & + & + \\
\hline PA-1 & $\begin{array}{l}\text { Ovary, } 12, \mathrm{~F} . \\
(\mathrm{E} / \mathrm{T})\end{array}$ & - & n.d. & + & + & + \\
\hline
\end{tabular}

a) E : Embryonal carcinoma in a broad sense, $\mathrm{T}$ : Teratoma, $\mathrm{C}$ : Choriocarcinoma,

$\mathrm{S}$ : Seminoma

b) n.d. : not described 
と解釈することもできる、しかし，分化能を有する ITO 株細胞拈よびNEC14株細胞と分化能に乏しい NEC8株細胞抢よびNEC15株細胞(5) との間に F9様抗 原にしても HLA にしても著しい差異は認められな い.

マウス EC 細胞は PNA, Lotus A, DBA などのレク チンに対するレセプターを有し，これらレセプターは 高分子量糖ペプチドに荷われており，また分化した細 胞ではこれらレセプターが失われることが知られてい る2526). われわれの検索では F9細胞に比べてヒト EC 細胞ではDBA レセプターは少ないが, PNA，および Lotus A と同じく $\alpha$-L-Fucose を認識するUEA-I に 対してはF9細胞同様かなりのレセプターを有してい ることが認められた。 既に Tera-I 株とPA-1株に関し ては，それらの細胞表面に高分子量糖ペプチドが存在 することが報告されているが27)，われわれの 4 株につ いても共同研究者関谷 ${ }^{28)}$, 桧垣ら ${ }^{29)}$ にってその細胞 表面に高分子量糖ペプチドが存在することが確認され ている.

今回の研究はマウスとヒトの EC 細胞の表面マー カーに関する類似点を明らかにするとともに，かなり の相違点があることも明らかした。特に従来マウスに おいてはstagespecificで, ヒトに扔いても胎児性癌と 胎児殬丸組織にのみ存在すると考光られていた SSEA-1が，ヒトの正常組織や腫湟のかなりのものに も存在する ${ }^{30}$ ことが明らかになった今日，今後この方 面の研究はヒト由来の分化抗原によってなされる必要 があり，またそれによってこそヒト EC 細胞の位置づ けも明らかになるであろう。

本研究は文部省科学研究費 (一般研究 $\mathrm{A}$, 研究課題番号 56440069 , 研究代表者：佐藤昭太郎)の補助を受けて行われ た.

F9抗体作製にあたって御協力いただいた医学部附属病院 放射線部渡辺強技師長, 日本抗体研究所水田敏信氏, 第一病 理学教室吉田亮技官に心より感謝いたします。

\section{文 献}

1) Mintz, B. and Illmensee, K.: Normal genetically mosaic mice produced from malignant teratocarcinoma cells. Proc. Nat. Acad. Sci. U.S.A., 72, 3585-3589, 1975.

2) Stevens, L.C. and Hummel, K.P.: A description of spontaneous congenital testicular teratomas in strain 129 mice. J. Nat. Cancer Inst., 18, 719-747, 1957.

3) Yamamoto, T., Komatsubara, S., Suzuki, T. and Oboshi, S. : In vitro cultivation of human testicular embryonal carcinoma and establishment of a new cell line. Gann, 70, 677-680, 1979.

4) 本山悌一, 山本尊彦, 関口守正, 佐藤昭太郎, 渡辺 英伸：ヒト胚細胞腫瘍株の $\alpha$-フェトプロティン 産生能と形態的分化の関連性について. 医学のあ ゆみ, 121，872-974， 1982.

5）本山悌一, 山本尊彦：七上胚細胞腫瘍の胎児性と 分化能に関する実験的研究. 日病会誌, 72(補 2), 6, 1983.

6) Artzt, K., Dubois, P., Bennett, D., Condamine, H., Babinet, C. and Jacob, F.: Surface antigens common to mouse cleavage embryos and primitive teratocarcinoma cell in culture. Proc. Nat. Acad. Sci. U.S.A., 70, 2988-2929, 1973.

7) Poulik, M.D., Ferrone, S., Pellegrino, M.A., Sevier, D.E., Oh, S.K. and Reisfeld, R.A.: Association of HL-A antigens and $\beta_{2}$-microglobulin. Concepts and questions. Transplant. Rev., 21, 106-125, 1974.

8）大星章一, 清藤 勉：ヒト白血病,リンパ腫由来長 期培養株の細胞起原. 1. Burkitt 腫湟小児リンパ 腫由来培養株の樹立, 医学のあゆみ, 74, 220-222, 1970.

9) Tanaka, K., Nabeshima, Y., Takahashi, H., Takeuchi, S., Nabeshima, Y. and Ogata, K.: Lack of effective messenger RNA for $\beta_{2}$-microglobulin in a gestational human choriocarcinoma cell line (GCH-1). Cancer Res., 41, 3639-3641, 1981.

10) Tanimoto, M., Takahashi, T. and Nishizuka, Y.: The expression of HLA on two cultured choriocarcinoma cell lines. Gann, 73, 27-34, 1982.

11）大星章一, 清藤 勉, 吉田紘一, 下里幸雄, 小出 勉, 佐野量造: 胃悪性絨毛上皮腫の組織培養. 日病 会誌，61，146-147，1972.

12）北條晴人：ヒト胃癌細胞培養株の樹立とその形態 学的特性. 新潟医学会誌, 91, 737-752, 1977.

13) Barnstable, C.J., Bodmer, W.F., Brown, G., Galfre, G., Milstein, C., Williams, A.F. and Ziegler, A.: Production of monoclonal antibodies to group A erythrocytes, HLA and other human cell surface antigens-new tools for genetic analysis. Cell, 14, 9-20, 1978.

14) Jacob, F.: Mouse teratocarcinoma and embryonic antigens. Immunol. Rev., 33, 3-32, 1977.

15) Solter, D. and Knowles, B.: Monoclonal antibody defining a stage-specific mouse em- 
bryonic antigen (SSEA-1). Proc. Nat. Acad. Sci. U.S.A., 75, 5565-5569, 1978.

16) Gachelin, G., Kemler, R., Kelly, F. and Jacob, F. : PCC4, a new cell surface antigen common to multipotential embryonal carcinoma cells, spermatozoa, and mouse early embryos. Devel. Biol., 57, 199-205, 1977.

17) Randle, B.J.: Cosegregation of monoclonal antibody reactivity and cell behaviour in the preimplantation mouse embryo. J. Embryol. Exptl. Morph., 70, 261-278, 1982.

18) Kawata, M., Higaki, K., Sekiya, S., Takamizawa, H., Muramatsu, T. and Okumura, K. : Antibodies to large glucopeptides in sera from patients with ovarian germ cell tumours. Clin. Exp. Immunol., 51, 401-405, 1983.

19) Hogan, B., Fellous, M., Avner, P., Jacob, F.: Isolation of a human teratoma cell line which expresses F9 antigen. Nature, 270, 515-518, 1977.

20) Holden, S., Bernard, O., Artzt, K., Whitmore, W.F. Jr. and Bennett, D. : Human and mouse embryonal carcinoma cells in culture share an embryonic antigen (F9). Nature, 270, 518-520, 1977.

21) Bronson, D.L., Andrews, P.W., Solter, D., Cervenka, J., Lange, P.H. and Fraley, E.E. : Cell line derived from a metastasis of a human testicular germ cell tumor. Cancer Res., 40, 2500-2506, 1980.

22) Zeuten, J., Norgaard, J.O.R., Avner, P., Fellous, M., Wartiovaara, J., Vaheri, A., Posen, A. and Giovanella, B.V.: Characterization of a human ovarian teratocarcinoma-derived cell line. Int. J. Cancer, 25, 19-32, 1980.

23) Andrews, P.W., Bronson, D.L., Benham, F., Strickland, S. and Knowles, B.B.: A compara- tive study of eight cell lines derived from human testicular teratocarcinoma. Int. J. Cancr, 26, 269-280, 1980.

24) Avner, P., Bono, R., Berger, R. and Fellous, M. : Characterization of human teratoma cell lines for their in vitro developmental properties and expression of embryonic and major histocompatibilitylocus-associated antigens. J. Immnogens., 8, 151-162, 1981.

25) Muramatsu, T., Gachelin, G., Damonneville, M., Delarbre, C. and Jacob, F.: Cell surface carbohydrates of embryonal carcinoma cells : Polysaccharidic side chains of F9 antigens and of receptors to two lectins. FBP and PNA. Cell, 18, 183-191, 1979.

26) Muramatsu, T., Muramatsu, H. and Ozawa, M. : Receptors for Dolichos biflorus agglutinin on embryonal carcinoma cells. J. Biochem., 89, 473-181, 1981.

27) Muramatsu, H., Muramatsu, T. and Avner, P. : Biochemical properties of the high molecularweight glycopeptides released from the cell surface of human teratocarcinoma cells. Cancer Res., 42, 1749-1752, 1982.

28）関谷宗英，私信.

29）桧垣康二, 関谷宗英, 河田 誠, 本山悌一, 山本尊 彦, 村松 喬, 奥村 康, 高見沢裕吉：悪性胚細胞 性腫瘍患者に検出される抗肧細胞（F9）抗体と反 応する胚細胞膜表面糖ペプチドの解析．第42回日 本癌学会総会記事 (名古屋), p. 100, 1983.

30) Fox, N., Damjanov, I., Knowles, B.B. and Solter, D.: Immkunohistochemical localization of the mouse stage specific embryonic antigen 1 in human tissues and tumors. Cancer Res., 43, 669-678, 1983.

（1984年 6 月 18 日受付） 